Brazilian Journal of Animal Science ISSN 1806-9290

www.rbz.org.br
Brasileira de Zootecnia
*Corresponding author:

emviegas@usp.br

Received: November 14, 2017

Accepted: October 30, 2018

How to cite: Natori, M. M.; Oliveira, R. H. F.; Parisi, G.; Bonelli, A.; Melo, M. P. and Viegas, E. M. M. 2019. Oil blends with sesame oil in fish diets: oxidative stress status and fatty acid profiles of lambari. Revista Brasileira de Zootecnia 48:e20170240.

https://doi.org/10.1590/rbz4820170240

Copyright: This is an open access article distributed under the terms of the

Creative Commons Attribution License

(http://creativecommons.org/licenses/by/4.0/) which permits unrestricted use, distribution, and reproduction in any medium, provided the original work is properly cited.

\section{Oil blends with sesame oil in fish diets: oxidative stress status and fatty acid profiles of lambari}

\author{
Mariene Miyoko Natori ${ }^{1}$ (iD, Ricardo Henrique Franco de Oliveira ${ }^{2}$ iD, \\ Giuliana Parisi ${ }^{3}$ (D), Antonio Bonelli ${ }^{3}$ (iD), Mariza Pires de Melo² $^{2}$ iD, \\ Elisabete Maria Macedo Viegas ${ }^{1^{*}}$ iD \\ ${ }^{1}$ Universidade de São Paulo, Faculdade de Zootecnia e Engenharia de Alimentos, \\ Departamento de Zootecnia, Pirassununga, SP, Brasil. \\ ${ }^{2}$ Universidade de São Paulo, Faculdade de Zootecnia e Engenharia de Alimentos, \\ Departamento de Ciências Básicas, Pirassununga, SP, Brasil. \\ ${ }^{3}$ University of Florence, Animal Sciences Section, Department of Agri-Food Production and \\ Environmental Sciences, Firenze, Italy.
}

\begin{abstract}
The objective of this research was to evaluate the growth performance, oxidative stress, and fatty acid profiles of lambari (Astyanax altiparanae) fed diets containing different lipid sources: soybean oil, linseed oil, and freshwater fish residue oil combined or otherwise with sesame oil (SEO). The fish (mean weight $0.95 \pm 0.46 \mathrm{~g}$; mean length $4.21 \pm 2.77 \mathrm{~cm}$ ) were distributed into 24 cages (cage capacity: $0.70 \mathrm{~m}^{3}$; fish density: 276 individuals $\mathrm{m}^{-3}$ ) in six treatments and four replicates. After 80 days of feeding, they were weighed, and samples were collected for assay of catalase, glutathione reductase (GR), and lactate dehydrogenase (LDH) enzyme activities in muscle and analysis of the fatty acid profiles of polar and neutral fractions of whole eviscerated fish. The addition of SEO reduced docosahexaenoic acid (C22:6n-3, DHA) levels but increased the percentage of highly unsaturated n-3 fatty acids and the DHA: eiocosapentaenoic acid ratio, while reduced GR and LDH enzyme activities in muscle. Thus, certain blends of oils added to fish diets can improve the lipid profile of lambari and protect consumers against reactive oxygen species.
\end{abstract}

Keywords: fish, lipid, nutrition, oxidation

The inclusion of large quantities of vegetable oils in aquafeed causes undesirable changes, such as increased levels of 18-carbon polyunsaturated fatty acids, mainly C18:2n-6 (linoleic acid, LA), and reduces the occurrence and quantity of highly unsaturated fatty acids (HUFA), such as C20:5n-3 (eicosapentaenoic acid, EPA) and C22:6n-3 (docosahexaenoic acid, DHA) (Ng et al., 2013). Sesame oil is considered as stable to oxidation due to its content of phenolic compounds such as sesamol derivatives (Turchini et al., 2009). Likewise, the addition of sesamin, a sesame lignan associated with sunflower and linseed oils, to aquafeed for rainbow trout (Oncorhynchus mykiss) promotes formation of DHA by acting on peroxisome $\beta$-oxidation (Trattner et al., 2008a).

Increased HUFA content in tissues elevates susceptibility to free radical production and lipid peroxidation (Ng et al., 2013). Studies demonstrate that lambari, Astyanax altiparanae (Garutti and 
Britski, 2000), probably has the capacity to desaturate and elongate LA and linolenic acid (LNA), contained in its diet, to HUFA, such as arachidonic acid (AA), EPA, and DHA (Gonçalves et al., 2012).

Lambari (Astyanax altiparanae) is a Brazilian native omnivore freshwater fish species that has basic characteristics such as fast growth rate, easy adaptation to the intensive production system, and a promising market for human consumption and live bait (Gonçalves et al., 2014). It may, therefore, be useful to obtain information about the nutrition, physiology, and feeding behavior of this native Brazilian species (Abimorad and Castellani, 2011; Gonçalves et al., 2014), which, due to its small size, can be studied as a model for other larger species.

In a recent study, lambari fed feed containing plant oils combined with sesame oil showed a higher n-3 desaturation index and a lower hepatic peroxidation index, quantified by thiobarbituric acid reactive substances (TBARS) levels (Natori et al., 2016). However, the effect of sesame oil on oxidative stress enzymes and its effect on the polar and neutral fraction profiles of fish, when given in feed, were not investigated.

The objective of this research was to evaluate the effect of diets including soy oil (SO), linseed oil (LO), or freshwater fish residue oil (FRO) with or without sesame oil (SEO) on the oxidative stress status and polar and neutral lipid fraction composition of lambari. The experimental diets contained higher levels of EPA and DHA than the diets tested by Natori et al. (2016) and were supplemented with biotin and pantothenic acid.

\section{Material and Methods}

The study was conducted according to case no. 2012.1.1435.74.8 of the institutional committee on animal use. The experimental design was completely randomized for the two factors tested: three oils, i.e., SO (Cargill Brazil Company, São Paulo, SP, Brazil), LO (Cisbra Ltda, Panambi, RS, Brazil), and FRO (donated by Nosso Recanto Trout Farm, Sapucaí Mirim, MG, Brazil), with or without SEO (Sum Sum Hong, São Paulo, SP, Brazil), totalizing six treatments and four replicates for each treatment.

The lambari (mean weight $0.95 \pm 0.46 \mathrm{~g}$; mean length $4.21 \pm 2.77 \mathrm{~cm}$ ) (from Instituto de Pesca, Pirassununga, Brazil) were distributed into 24 cages (capacity $0.70 \mathrm{~m}^{3}$ ) at a density of 276 fish $\mathrm{m}^{-3}$ corresponding to a biomass of $272.20 \mathrm{~g} \mathrm{~m}^{-3}$, installed in two ponds in Pirassununga, São Paulo, Brazil

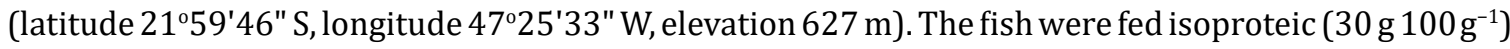
and isocaloric (4239 kcal $100 \mathrm{~g}^{-1}$ ) diets, which formulation (Table 1) was based on studies carried out

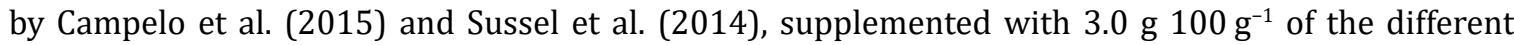
kinds of oil (SO, LO, or FRO) with or without $1.50100 \mathrm{~g}^{-1}$ SEO (estimated to contain $37.50 \mathrm{mg} 100 \mathrm{~g}^{-1}$ of sesamin/episamin; Trattner et al., 2008a). In addition, a quantity corresponding to $2 \mathrm{mg}$ of biotin and $50 \mathrm{mg}$ of calcium pantothenate was added to the diets. The chemical composition (Table 1) and fatty acids profile (Table 2) of experimental diets were determined by AOAC (1990) and AOAC (2005; method 966.06), respectively.

During the feeding trial, water quality parameters in the cages were monitored on alternate days. Temperature, dissolved oxygen, and $\mathrm{pH}$ were measured with a multi-parameter water quality meter (U-10 Horiba, Kyoto, Japan). Total and soluble phosphorus, nitrite, and nitrate levels were determined with specific kits (Hanna Instruments, Woonsocket, RI, USA).

After a period of 80 days of feeding twice a day (at 9:00 and 16:00 h), the individuals in each cage were anesthetized with clove oil (50 $\mathrm{mg} \mathrm{L}^{-1}$ water) (Pereira-da-Silva et al., 2009), slaughtered by cranial drilling, and weighed. The following performance variables were calculated: feed intake, weight gain, feed conversion ratio, protein efficiency ratio, and specific growth rate. Muscle samples as well as eviscerated fish were analyzed as detailed below.

Catalase, glutathione reductase, and lactate dehydrogenase enzyme activities were assayed in white muscle homogenate from seven fish per treatment. Muscle samples (each $0.50 \mathrm{~g}$ ) were homogenized with $1.25 \mathrm{~mL}$ cold $10 \mathrm{mM}$ sodium phosphate buffer (Sigma Aldrich, Spruce St. Louis,

R. Bras. Zootec., 48:e20170240, 2019 
MO, USA) at pH 7.4 using a Potter type homogenizer (Tecnal, Piracicaba, SP, Brazil). The samples were centrifuged for $10 \mathrm{~min}$ at $10,000 \mathrm{rpm}$ at $4{ }^{\circ} \mathrm{C}$, and the supernatants were transferred to micro-tubes inserted in ice. The protein content of each sample was determined by the Bradford (1976) method, and bovine serum albumin (Sigma Aldrich, Spruce St. Louis, MO, USA) was used to obtain the standard curve.

Catalase (CAT) activity was measured as hydrogen peroxide $\left(\mathrm{H}_{2} \mathrm{O}_{2}\right)$ consumption for 3 min at $25{ }^{\circ} \mathrm{C}$ (Beers and Sizer, 1952) and read at $240 \mathrm{~nm}$ using a DU-800 spectrophotometer (Beckman Coulter, Brea, CA, USA). Results were expressed in $\mu \mathrm{mol}$ of $\mathrm{H}_{2} \mathrm{O}_{2}$ per minute per mg of protein. For this analysis, $20 \mu \mathrm{L}$ of each homogenate was added to assay medium containing $980 \mu \mathrm{L}$ potassium phosphate buffer $50 \mathrm{mM} \mathrm{pH} \mathrm{7.0} \mathrm{(code} \mathrm{P5379,} \mathrm{Sigma} \mathrm{Aldrich,} \mathrm{Spruce} \mathrm{St.} \mathrm{Louis,} \mathrm{MO,} \mathrm{USA)} \mathrm{and} \mathrm{H}_{2} \mathrm{O}_{2} 10 \mathrm{mM}$ (code $\mathrm{H} 1009$ Sigma Aldrich, Spruce St. Louis, MO, USA).

Table 1 - Ingredients, formulation, and composition of the experimental diets for lambari

\begin{tabular}{|c|c|c|c|c|c|c|}
\hline \multirow{2}{*}{ Item } & \multicolumn{6}{|c|}{ Diet } \\
\hline & so & LO & FRO & $\mathrm{SO}+\mathrm{SEO}$ & $\mathrm{LO}+\mathrm{SEO}$ & $\mathrm{FRO}+\mathrm{SEO}$ \\
\hline \multicolumn{7}{|l|}{ Ingredient ( $\mathrm{g} \mathrm{kg}^{-1}$ ) } \\
\hline Corn meal & 267.1 & 267.1 & 267.1 & 267.1 & 267.1 & 267.1 \\
\hline Viscera meal & 120.0 & 120.0 & 120.0 & 120.0 & 120.0 & 120.0 \\
\hline Soybean meal & 137.3 & 137.3 & 137.3 & 137.3 & 137.3 & 137.3 \\
\hline Wheat meal & 220.0 & 220.0 & 220.0 & 220.0 & 220.0 & 220.0 \\
\hline Sugar cane yeast & 5.0 & 5.0 & 5.0 & 5.0 & 5.0 & 5.0 \\
\hline Rice meal & 80.0 & 80.0 & 80.0 & 80.0 & 80.0 & 80.0 \\
\hline Meat meal & 70.0 & 70.0 & 70.0 & 70.0 & 70.0 & 70.0 \\
\hline Fishmeal & 55.0 & 55.0 & 55.0 & 55.0 & 55.0 & 55.0 \\
\hline Dicalcium phosphate & 4.1 & 4.1 & 4.1 & 4.1 & 4.1 & 4.1 \\
\hline Soybean oil & 30.0 & - & - & 15.0 & - & - \\
\hline Linseed oil & - & 30.0 & - & - & 15.0 & - \\
\hline Freshwater fish residue oil & - & - & 30.0 & - & - & 15.0 \\
\hline Sesame oil & - & - & - & 15.0 & 15.0 & 15.0 \\
\hline Chlorine chloride & 1.0 & 1.0 & 1.0 & 1.0 & 1.0 & 1.0 \\
\hline L-lysine & 1.1 & 1.1 & 1.1 & 1.1 & 1.1 & 1.1 \\
\hline DL-methionine & 1.3 & 1.3 & 1.3 & 1.3 & 1.3 & 1.3 \\
\hline Antioxidant & 0.1 & 0.1 & 0.1 & 0.1 & 0.1 & 0.1 \\
\hline Antifungal & 1.0 & 1.0 & 1.0 & 1.0 & 1.0 & 1.0 \\
\hline Vitamin and mineral supplement ${ }^{1}$ & 5.0 & 5.0 & 5.0 & 5.0 & 5.0 & 5.0 \\
\hline Common salt & 2.0 & 2.0 & 2.0 & 2.0 & 2.0 & 2.0 \\
\hline \multicolumn{7}{|l|}{ Chemical composition (g $100 \mathrm{~g}^{-1}$ ) } \\
\hline Dry matter & 96.59 & 96.58 & 97.26 & 97.21 & 96.36 & 97.29 \\
\hline Crude protein & 30.45 & 31.69 & 30.39 & 29.52 & 30.18 & 30.16 \\
\hline Ether extract & 6.88 & 7.68 & 8.19 & 8.44 & 8.35 & 8.26 \\
\hline Ash & 10.16 & 10.34 & 10.04 & 10.19 & 10.07 & 10.13 \\
\hline Crude energy (MJ kg-1) & 17.75 & 17.79 & 17.64 & 17.73 & 17.77 & 17.78 \\
\hline
\end{tabular}

SO - soybean oil; LO - linseed oil; FRO - fresh water fish residue oil; SEO - sesame oil.

${ }^{1}$ Vitamin and mineral supplement $\left(0.50 \mathrm{~g} \mathrm{~kg}^{-1}\right)$ : vitamin A, 12,000 UI; vitamin D3, 3,000 UI; vitamin E, $150 \mathrm{mg}$; vitamin K3, $15 \mathrm{mg}$; vitamin B2, $20 \mathrm{mg}$; vitamin B6, $17.50 \mathrm{mg}$; vitamin B12, $40 \mu \mathrm{g}$; vitamin C, $300 \mathrm{mg}$; nicotinic acid, $100 \mathrm{mg}$; calcium pantothenate, $100 \mathrm{mg}$; biotin, $2.00 \mathrm{mg}$; folic acid, $6 \mathrm{mg}$; copper sulphate, $17.50 \mathrm{mg}$; iron sulfate, $100 \mathrm{mg}$; manganese sulphate, $50 \mathrm{mg}$; zinc sulfate, $120 \mathrm{mg}$; calcium iodide, $0.80 \mathrm{mg}$; sodium sulfate, $0.50 \mathrm{mg}$; cobalt sulphate, $0.40 \mathrm{mg}$; inositol, $125 \mathrm{mg}$; choline chloride, $500 \mathrm{mg}$. 
Glutathione reductase (GR) activity was evaluated as NADPH oxidation and consequent reduction of oxidized glutathione (GSSG) at $25^{\circ} \mathrm{C}$ for $3 \mathrm{~min}$ by spectrophotometry (Beckman Coulter, Pasadena, CA, USA) reading at $340 \mathrm{~nm}$ (Carlberg and Mannervik, 1985). Results were expressed in nmol of oxidized NADPH per minute per mg protein. For this analysis, a $40-\mu \mathrm{L}$ aliquot of homogenate was added to an assay medium containing $500 \mu \mathrm{L}$ potassium phosphate $100 \mathrm{mM} \mathrm{pH} 7.0$ (code P5379, Sigma Aldrich, Spruce St. Louis, MO, USA) containing 1 mM EDTA (code E1644, Sigma Aldrich, Spruce St. Louis, MO, USA), $5 \mu$ L NADPH $0.10 \mathrm{mM}$ (code N1630, Sigma Aldrich, Spruce St. Louis, MO, USA), and $50 \mu \mathrm{L}$ GSSG 1.0 mM (code G6654, Sigma Aldrich, Spruce St. Louis, MO, USA).

Lactate dehydrogenase (LDH) activity was evaluated as oxidation of $\mathrm{NADH}$ at $25^{\circ} \mathrm{C}$ for 3 min using a DU-800 Beckman Coulter spectrophotometer read at $340 \mathrm{~nm}$ (Bernt and Bergmeyer, 1974). Results were expressed in $\mu \mathrm{mol}$ of oxidized NADH per minute per mg protein. For this analysis, $10 \mu \mathrm{L}$ diluted homogenate $(1: 50, \mathrm{v}: \mathrm{v})$ were added to $990 \mu \mathrm{L}$ assay medium containing $123.75 \mu \mathrm{L}$ sodium phosphate buffer 20 mM pH 7.4 (code S8282, Sigma Aldrich, Spruce St. Louis, MO, USA), $12.37 \mu$ L pyruvic acid

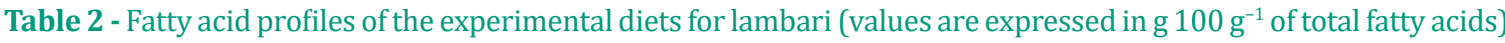

\begin{tabular}{|c|c|c|c|c|c|c|}
\hline \multirow{2}{*}{ Fatty acid } & \multicolumn{6}{|c|}{ Diet } \\
\hline & SO & LO & FRO & SO+SEO & $\mathrm{LO}+\mathrm{SEO}$ & $\mathrm{FRO}+\mathrm{SEO}$ \\
\hline $\mathrm{C} 12: 0$ & 0.04 & 0.03 & 0.07 & 0.00 & 0.00 & 0.10 \\
\hline C14:0 & 1.06 & 0.88 & 1.39 & 0.98 & 1.20 & 1.54 \\
\hline $\mathrm{C} 15: 0$ & 0.17 & 0.18 & 0.20 & 0.19 & 0.28 & 0.25 \\
\hline $\mathrm{C} 16: 0$ & 15.88 & 13.89 & 19.56 & 15.74 & 14.29 & 17.33 \\
\hline C16:1 & 2.24 & 1.92 & 5.20 & 2.07 & 2.56 & 4.37 \\
\hline $\mathrm{C} 17: 0$ & 0.25 & 0.22 & 0.28 & 0.25 & 0.18 & 0.20 \\
\hline C18:0 & 4.62 & 5.63 & 5.88 & 5.23 & 4.41 & 4.67 \\
\hline C18:1n-9 & 24.77 & 23.13 & 31.15 & 28.95 & 24.32 & 29.86 \\
\hline C18:2n-6 (LA) & 43.99 & 25.55 & 28.72 & 41.18 & 32.86 & 35.74 \\
\hline C18:3n-6 & 0.07 & 0.05 & 0.35 & 0.00 & 0.00 & 0.25 \\
\hline C18:3n-3 (LNA) & 3.97 & 25.57 & 1.69 & 2.72 & 17.33 & 1.89 \\
\hline $\mathrm{C} 20: 0$ & 0.19 & 0.17 & 0.16 & 0.23 & 0.12 & 0.10 \\
\hline$C 20: 2 n-6$ & 0.06 & 0.06 & 0.55 & 0.05 & 0.00 & 0.26 \\
\hline$C 20: 3 n-6$ & 0.07 & 0.05 & 0.52 & 0.08 & 0.00 & 0.26 \\
\hline C20:4n-6 (AA) & 0.45 & 0.42 & 0.94 & 0.39 & 0.47 & 0.75 \\
\hline$C 20: 3 n-3$ & 0.00 & 0.03 & 0.04 & 0.00 & 0.00 & 0.00 \\
\hline C20:5n-3 (EPA) & 0.43 & 0.42 & 0.47 & 0.40 & 0.47 & 0.48 \\
\hline $\mathrm{C} 22: 0$ & 0.16 & 0.11 & 0.06 & 0.13 & 0.00 & 0.05 \\
\hline C22:1n-9 & 0.00 & 0.02 & 0.10 & 0.00 & 0.00 & 0.00 \\
\hline$C 22: 2 n-6$ & 0.00 & 0.00 & 0.05 & 0.00 & 0.00 & 0.00 \\
\hline $\mathrm{C} 24: 0$ & 0.09 & 0.06 & 0.06 & 0.07 & 0.00 & 0.00 \\
\hline C22:6n-3 (DHA) & 1.06 & 1.03 & 1.39 & 1.01 & 1.03 & 1.19 \\
\hline$\Sigma$ SFA & 22.46 & 21.17 & 27.66 & 22.82 & 20.48 & 24.24 \\
\hline$\Sigma$ MUFA & 27.01 & 25.07 & 36.45 & 31.02 & 26.88 & 34.23 \\
\hline$\Sigma$ PUFA & 50.04 & 53.12 & 34.12 & 45.78 & 52.16 & 40.56 \\
\hline$\Sigma$ PUFAn-6 & 44.64 & 26.13 & 31.13 & 41.7 & 33.33 & 37.26 \\
\hline ¿PUFAn-3 & 5.46 & 27.05 & 3.59 & 4.13 & 18.83 & 3.56 \\
\hline 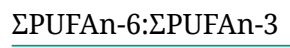 & 8.18 & 0.97 & 8.67 & 10.1 & 1.77 & 10.47 \\
\hline
\end{tabular}

SO - soybean oil; LO - linseed oil; FRO - fresh water fish residue oil; SEO - sesame oil; LA - linoleic acid; LNA - linolenic acid; AA arachidonic acid; EPA - eicosapentaenoic acid; DHA - docosahexaenoic acid; SFA - saturated fatty acids; MUFA - monounsaturated fatty acids; PUFA - polyunsaturated fatty acids. 
1.0 mM (code P2256, Sigma Aldrich, Spruce St. Louis, MO, USA), $12.37 \mu \mathrm{L}$ NADH $0.10 \mathrm{mM}$ (code N8129, Sigma Aldrich, Spruce St. Louis, MO, USA), and $841.50 \mu \mathrm{L}$ ultrapure water.

Fatty acid (FA) profile was determined in pools of 10 individuals per replicate, totalizing 40 animals (i.e., four pools) per treatment. For each pool, the fish were eviscerated, freeze-dried, minced, and stored in a box. Lipid extraction was done according to the method of Folch et al. (1957). The samples were homogenized in chloroform and methanol solution $(2: 1 \mathrm{v} / \mathrm{v}$, with $0.01 \%$ BHT $)$ and then filtered. The lipid extract was washed with $0.88 \% \mathrm{KCl}$ solution, and the solvents removed by Rotavapor. The purified lipid extract was dissolved in $5 \mathrm{~mL}$ chloroform and stored in sealed amber glass bottles. Nitrogen was added to the bottles before sealing to prevent oxidation, which were stored in a freezer at $-20{ }^{\circ} \mathrm{C}$ until analysis.

Neutral and polar lipid fractions were separated according to Juaneda and Rocquelin (1985) using a Sep-Pak ${ }^{\circledR}$ silica cartridge (Waters Company, Milford, MA, USA): $30 \mathrm{mg}$ lipid dissolved in $500 \mu \mathrm{L}$ chloroform (Sigma Aldrich, St. Louis, MO, USA) were applied to each cartridge. The cartridge was placed in a $50 \mathrm{~mL}$ syringe, and the neutral fraction was extracted by injecting $20 \mathrm{~mL}$ chloroform and $5 \mathrm{~mL}$ chloroform-methanol solution (49:1 v/v). The polar fraction (phospholipids) was extracted by injecting $30 \mathrm{~mL}$ methanol.

Fatty acid profiles of neutral and polar fractions were obtained in two steps: saponification with $\mathrm{KOH}$ $0.5 \mathrm{~N}$ in methanol and esterification with boron trifluoride-methanol solution $\left(\mathrm{BF}_{3} 14 \%\right.$; code $\mathrm{B} 1252$, Sigma Aldrich, St. Louis, MO, USA), according to Morrison and Smith (1964). The fatty acid methyl esters (FAME) obtained were analyzed by gas chromatography (model 430-GC with CP-8400 auto sampler; Varian Inc., Mitchell Drive Walnut Creek, CA, USA) with flame ionization detection (GC-FID) on an Omegawax ${ }^{\circledR}$ Capillary GC Column $(30 \mathrm{~m} \times 0.32 \mathrm{~mm} \times 0.25 \mu \mathrm{m}$ film thickness; code 24152 Supelco, Sigma Aldrich, Spruce St. Louis, MO, USA), using helium as carrier gas. The gas chromatograph temperature cycle was programmed as follows: $90^{\circ} \mathrm{C}$ for $1 \mathrm{~min}$; heat to $180{ }^{\circ} \mathrm{C}$ at $20^{\circ} \mathrm{C} \mathrm{min}^{-1}$, and then to $220^{\circ} \mathrm{C}$ at $3{ }^{\circ} \mathrm{C} \mathrm{min}^{-1}$. The duration of gas chromatograph analysis was $40 \mathrm{~min}$ for each sample.

The chromatograms were recorded with integrator software (Galaxie Chromatography Data System 1.9.302.952; Varian Inc., Mitchell Drive Walnut Creek, CA, USA) and the FA were identified by comparing the retention time of FAME with the standard C4-C24 FAME mix (code 18919 Supelco, Sigma Aldrich, Spruce St. Louis, MO, USA). Fatty acids were quantified through three levels of calibration curve, built using the same C4-C24 FAME mix with tricosanoic acid (C23:0; code T6543, Sigma Aldrich, Spruce St. Louis, MO, USA) as internal standard.

The data was analysed by the GLM procedure of SAS software (Statistical Analysis System, version 9.2), considering the two factors, i.e., kind of oil (three levels: SO, LO, FRO) and presence/absence of sesame oil (two levels: with or without), and their interaction in the statistical model. Significant differences between treatments were detected by $\mathrm{F}$ test.

\section{Results}

During the trial, temperature, dissolved oxygen, $\mathrm{pH}$, total and soluble phosphorus, nitrites, and nitrates were in the following ranges: $26.53-28.55{ }^{\circ} \mathrm{C}, 6.39-6.90 \mathrm{mg} \mathrm{L}^{-1}, 5.58-6.35,0.01-0.10 \mathrm{mg} \mathrm{L}^{-1}$, 0.00-0.09 $\mathrm{mg} \mathrm{L}^{-1}, 1.00-4.00 \mathrm{mg} \mathrm{L}^{-1}$, and 0.00-1.50 $\mathrm{mg} \mathrm{L}^{-1}$, respectively.

As expected, the addition of SEO to SO, LO, or FRO did not cause any reduction in growth performance variables $(\mathrm{P}>0.05)$ (Table 3), but it determined a reduction in GR and LDH activities in muscle $(\mathrm{P}<0.05)$. The highest GR activity was found in fish fed the FRO diet. Catalase activity was similar in all groups, proving unaffected by the different lipid sources and by addition of SEO (Table 4).

The fatty acid profiles showed that SO, LO, and FRO plus SEO modified neutral and polar lipid profiles $(\mathrm{P}<0.05)$ (Tables 5 and 6).

A significant interaction between SEO and the kind of oil tested was found for the following fatty acids of neutral and polar lipids: linoleic acid (C18:2n-6), linolenic acid (C18:3n-3), arachidonic acid 
(C20:4n-3), and eiocosapentaenoic acid (C20:5n-3). The higher polyunsaturated fatty acids (PUFA) and PUFAn-3 contents were detected in fish fed the LO diet.

The HUFAn-3:LNA ratio showed higher values in fish fed SEO, demonstrating their probable capacity to convert LNA into HUFAn-3. The DHA:EPA ratio was also lower in fish fed the LO diet than in those fed the LO+SEO diet (Tables 5 and 6). As expected, the polar fraction showed higher PUFA (AA, EPA, and DHA) than monounsaturated fatty acids (MUFA) and saturated fatty acids (SFA) contents, and lower PUFAn-6:PUFAn-3 ratios and lower percentages of LA and LNA than the neutral fraction.

Table 3 - Mean values of growth performance variables of lambari

\begin{tabular}{|c|c|c|c|c|c|c|c|c|c|}
\hline \multirow{2}{*}{ Item } & \multirow{2}{*}{ SEO } & \multicolumn{3}{|c|}{ Oil source (OS) } & \multirow{2}{*}{ Mean } & \multicolumn{3}{|c|}{ P-value } & \multirow{2}{*}{ RSD } \\
\hline & & SO & LO & FRO & & OS & SEO & OS $\times$ SEO & \\
\hline & Without & 7.94 & 7.81 & 7.48 & 7.74 & & & & \\
\hline \multirow[t]{3}{*}{ FI $\left(\mathrm{g} \mathrm{fish}^{-1}\right)$} & With & 8.22 & 7.16 & 7.66 & 7.68 & 0.19 & 0.81 & 0.33 & 0.68 \\
\hline & Mean & 8.08 & 7.48 & 7.57 & & & & & \\
\hline & Without & 6.06 & 6.01 & 5.68 & 6.04 & & & & \\
\hline \multirow[t]{3}{*}{ WG (g fish ${ }^{-1}$ ) } & With & 6.10 & 5.39 & 5.50 & 5.81 & 0.32 & 0.36 & 0.40 & 0.61 \\
\hline & Mean & 6.20 & 5.78 & 5.79 & & & & & \\
\hline & Without & 1.31 & 1.30 & 1.32 & 1.28 & & & & \\
\hline \multirow[t]{3}{*}{ FCR } & With & 1.36 & 1.33 & 1.42 & 1.33 & 0.95 & 0.37 & 0.85 & 0.14 \\
\hline & Mean & 1.31 & 1.30 & 1.32 & & & & & \\
\hline & Without & 2.53 & 2.43 & 2.50 & 2.54 & & & & \\
\hline \multirow[t]{3}{*}{ PER } & With & 2.51 & 2.50 & 2.38 & 2.52 & 0.86 & 0.91 & 0.73 & 0.26 \\
\hline & Mean & 2.57 & 2.50 & 2.53 & & & & & \\
\hline & Without & 2.43 & 2.43 & 2.37 & 2.43 & & & & \\
\hline \multirow[t]{2}{*}{ SGR $\left(\%\right.$ day $\left.^{-1}\right)$} & With & 2.44 & 2.31 & 2.32 & 2.38 & 0.32 & 0.30 & 0.39 & 0.11 \\
\hline & Mean & 2.46 & 2.38 & 2.38 & & & & & \\
\hline
\end{tabular}

SO - soybean oil; LO - linseed oil; FRO - fresh water fish residue oil; SEO - sesame oil; FI - feed intake; WG - weight gain; FC - feed conversion ratio; PER - protein efficiency ratio; SGR - specific growth rate; RSD - residual standard deviation.

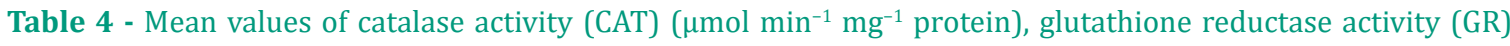
(nmol min ${ }^{-1} \mathrm{mg}^{-1}$ protein), and lactate dehydrogenase (LDH) ( $\mu \mathrm{mol} \mathrm{min}{ }^{-1} \mathrm{mg}^{-1}$ protein)

\begin{tabular}{|c|c|c|c|c|c|c|c|c|c|}
\hline \multirow{2}{*}{ Item } & \multirow{2}{*}{ SEO } & \multicolumn{3}{|c|}{ Oil Source (OS) } & \multirow{2}{*}{ Mean } & \multicolumn{3}{|c|}{ P-value } & \multirow{2}{*}{ RSD } \\
\hline & & SO & $\mathrm{LO}$ & FRO & & OS & SEO & $\mathrm{OS} \times \mathrm{SEO}$ & \\
\hline \multirow{3}{*}{ CAT } & Without & 0.79 & 0.73 & 0.71 & 0.74 & & & & \\
\hline & With & 0.73 & 0.44 & 0.75 & 0.64 & 0.60 & 0.50 & 0.68 & 0.52 \\
\hline & Mean & 0.76 & 0.58 & 0.73 & & & & & \\
\hline \multirow{3}{*}{ GR } & Without & 1.48 & 1.49 & 2.61 & $1.86 \mathrm{a}$ & & & & \\
\hline & With & 1.41 & 1.32 & 1.60 & $1.44 \mathrm{~b}$ & 0.005 & 0.031 & 0.09 & 0.63 \\
\hline & Mean & $1.44 \mathrm{~B}$ & $1.40 \mathrm{~B}$ & $2.10 \mathrm{~A}$ & & & & & \\
\hline \multirow{3}{*}{$\mathrm{LDH}$} & Without & 4.98 & 4.92 & 4.82 & $4.91 \mathrm{a}$ & & & & \\
\hline & With & 4.83 & 3.96 & 3.79 & $4.19 \mathrm{~b}$ & 0.36 & 0.046 & 0.53 & 1.21 \\
\hline & Mean & 4.91 & 4.44 & 4.31 & & & & & \\
\hline
\end{tabular}

SO - soybean oil; LO - linseed oil; FRO - fresh water fish residue oil; SEO - sesame oil; RSD - residual standard deviation. Within criterion, mean values with different lowercase and uppercase letters in columns and rows, respectively, are significantly different at $\mathrm{P}<0.05$. 
Table 5 - Main fatty acids, fatty acid groups, and relationships in the neutral lipid fraction of lambari (values are

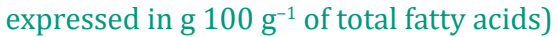

\begin{tabular}{|c|c|c|c|c|c|c|c|c|c|}
\hline \multirow{2}{*}{ Item } & \multirow{2}{*}{ SEO } & \multicolumn{3}{|c|}{ Oil Source (OS) } & \multirow{2}{*}{ Mean } & \multicolumn{3}{|c|}{ P-value } & \multirow{2}{*}{ RSD } \\
\hline & & SO & LO & FRO & & OS & SEO & $\mathrm{OS} \times \mathrm{SEO}$ & \\
\hline & Without & $0.98 \mathrm{a}$ & $0.86 \mathrm{~b}$ & $0.90 \mathrm{a}$ & 0.91 & & & & \\
\hline \multirow[t]{3}{*}{ C12:0 } & With & $0.90 \mathrm{~b}$ & $0.87 a$ & $0.91 \mathrm{a}$ & 0.85 & 0.0002 & 0.22 & 0.02 & 0.03 \\
\hline & Mean & 0.94 & 0.86 & 0.90 & & & & & \\
\hline & Without & 1.77 & 1.60 & 1.75 & 1.71 & & & & \\
\hline \multirow[t]{3}{*}{ C14:0 } & With & 1.70 & 1.65 & 1.77 & 1.70 & $<0.0001$ & 0.92 & 0.05 & 0.044 \\
\hline & Mean & $1.73 \mathrm{~A}$ & $1.63 \mathrm{~B}$ & $1.76 \mathrm{~A}$ & & & & & \\
\hline & Without & 18.56 & 17.57 & 19.13 & 18.42 & & & & \\
\hline \multirow[t]{3}{*}{ C16:0 } & With & 18.62 & 18.26 & 18.98 & 18.62 & 0.01 & 0.48 & 0.45 & 0.68 \\
\hline & Mean & $18.59 \mathrm{AB}$ & 17.91B & $19.05 \mathrm{~A}$ & & & & & \\
\hline & Without & 7.85 & 8.10 & 8.13 & 8.03 & & & & \\
\hline \multirow[t]{3}{*}{ C18:0 } & With & 814 & 8.17 & 7.92 & 8.07 & 0.39 & 0.58 & 0.08 & 0.20 \\
\hline & Mean & 7.99 & 8.13 & 8.03 & & & & & \\
\hline & Without & 36.67 & 36.05 & 38.06 & 36.92 & & & & \\
\hline \multirow[t]{3}{*}{ C18:1n-9 } & With & 37.68 & 36.93 & 37.59 & 37.40 & 0.22 & 0.44 & 0.56 & 1.49 \\
\hline & Mean & 37.18 & 36.49 & 37.83 & & & & & \\
\hline & Without & $14.11 \mathrm{a}$ & $10.38 \mathrm{a}$ & $10.79 a$ & 14.10 & & & & \\
\hline \multirow[t]{3}{*}{ C18:2n-6 } & With & $12.26 \mathrm{~b}$ & $11.58 \mathrm{a}$ & $11.48 \mathrm{a}$ & 12.26 & $<0.001$ & 0.98 & 0.004 & 0.83 \\
\hline & Mean & 13.18 & 10.98 & 11.13 & & & & & \\
\hline & Without & $1.51 \mathrm{a}$ & $6.36 a$ & $1.09 \mathrm{a}$ & 2.99 & & & & \\
\hline \multirow[t]{3}{*}{ C18:3n-3 } & With & $1.15 \mathrm{~b}$ & $3.48 \mathrm{~b}$ & $0.98 \mathrm{a}$ & 1.87 & $<0.001$ & $<0.001$ & $<0.001$ & 0.13 \\
\hline & Mean & 1.33 & 4.92 & 1.04 & & & & & \\
\hline & Without & $0.80 \mathrm{a}$ & $0.56 \mathrm{~b}$ & $0.84 a$ & 0.74 & & & & \\
\hline \multirow[t]{3}{*}{ C20:4n-6 } & With & $0.78 \mathrm{a}$ & $0.66 \mathrm{a}$ & $0.85 a$ & 0.76 & $<0.0001$ & 0.09 & 0.01 & 0.04 \\
\hline & Mean & 0.79 & 0.61 & 0.84 & & & & & \\
\hline & Without & $0.42 \mathrm{a}$ & $0.57 \mathrm{a}$ & $0.36 \mathrm{a}$ & 0.42 & & & & \\
\hline \multirow[t]{3}{*}{$C 20: 5 n-3$} & With & $0.37 \mathrm{~b}$ & $0.47 \mathrm{~b}$ & $0.37 \mathrm{a}$ & 0.37 & $<0.0001$ & $<0.0001$ & 0.0004 & 0.02 \\
\hline & Mean & 0.39 & 0.52 & 0.36 & & & & & \\
\hline & Without & 1.48 & 1.63 & 1.36 & $1.49 a$ & & & & \\
\hline \multirow[t]{3}{*}{ C22:6n-3 } & With & 1.33 & 1.49 & 1.31 & $1.37 \mathrm{~b}$ & $<0.0001$ & $<0.0001$ & 0.17 & 0.05 \\
\hline & Mean & $1.40 \mathrm{~B}$ & $1.56 \mathrm{~A}$ & $1.33 \mathrm{C}$ & & & & & \\
\hline & Without & 30.27 & 30.86 & 32.73 & 31.28 & & & & \\
\hline \multirow[t]{3}{*}{$\Sigma$ SFA } & With & 32.18 & 31.70 & 32.43 & 31.10 & 0.15 & 0.20 & 0.36 & 1.51 \\
\hline & Mean & 31.22 & 31.28 & 32.58 & & & & & \\
\hline & Without & 44.39 & 43.10 & 46.45 & 44.64 & & & & \\
\hline \multirow[t]{3}{*}{$\Sigma$ MUFA } & With & 45.34 & 44.17 & 45.84 & 45.11 & 0.01 & 0.46 & 0.49 & 1.54 \\
\hline & Mean & $44.86 \mathrm{AB}$ & 43.63B & $46.14 \mathrm{~A}$ & & & & & \\
\hline & Without & $25.35 a$ & $26.04 a$ & $20.82 \mathrm{a}$ & 24.07 & & & & \\
\hline \multirow[t]{3}{*}{ ¿PUFA } & With & $22.48 \mathrm{~b}$ & $24.12 \mathrm{~b}$ & $21.73 a$ & 22.77 & $<0.0001$ & 0.007 & 0.005 & 1.03 \\
\hline & Mean & 23.91 & 25.08 & 21.27 & & & & & \\
\hline & Without & $17.74 a$ & $13.11 b$ & $14.40 \mathrm{a}$ & 15.08 & & & & \\
\hline \multirow[t]{3}{*}{ ¿PUFAn-6 } & With & $15.70 \mathrm{~b}$ & $14.60 \mathrm{a}$ & $15.06 \mathrm{a}$ & 15.11 & $<0.0001$ & 0.92 & 0.001 & 0.82 \\
\hline & Mean & 16.72 & 13.85 & 14.73 & & & & & \\
\hline & & & & & & & & \multicolumn{2}{|c|}{ Continues... } \\
\hline
\end{tabular}




\begin{tabular}{|c|c|c|c|c|c|c|c|c|c|}
\hline \multirow{3}{*}{ ¿PUFAn-3 } & Without & $4.81 \mathrm{a}$ & $10.32 \mathrm{a}$ & $4.04 \mathrm{a}$ & 6.39 & & & & \\
\hline & With & $4.10 \mathrm{~b}$ & $6.93 \mathrm{~b}$ & $3.94 \mathrm{a}$ & 4.99 & $<0.0001$ & $<0.0001$ & $<0.0001$ & 0.16 \\
\hline & Mean & 4.45 & 8.62 & 3.99 & & & & & \\
\hline \multirow{3}{*}{$\begin{array}{l}\text { PUFAn-6: } \\
\text { PUFAn-3 }\end{array}$} & Without & $3.69 \mathrm{~b}$ & $1.27 \mathrm{~b}$ & $3.56 \mathrm{a}$ & 2.84 & & & & \\
\hline & With & $3.83 a$ & $2.10 \mathrm{a}$ & $3.83 a$ & 3.25 & $<0.0001$ & $<0.0001$ & 0.0008 & 0.16 \\
\hline & Mean & 3.76 & 1.68 & 3.70 & & & & & \\
\hline \multirow{3}{*}{ PUFA:SFA } & Without & $0.79 a$ & $0.84 \mathrm{a}$ & $0.64 a$ & 0.75 & & & & \\
\hline & With & $0.70 \mathrm{a}$ & $0.76 \mathrm{~b}$ & $0.67 a$ & 0.71 & $<0.0001$ & 0.016 & 0.017 & 0.04 \\
\hline & Mean & 0.74 & 0.80 & 0.65 & & & & & \\
\hline \multirow{3}{*}{ DHA:EPA } & Without & $3.51 \mathrm{a}$ & $2.87 \mathrm{~b}$ & $3.74 a$ & 3.37 & & & & \\
\hline & With & $3.64 a$ & $3.15 a$ & $3.57 \mathrm{~b}$ & 3.45 & $<0.0001$ & 0.16 & 0.007 & 0.13 \\
\hline & Mean & 3.57 & 3.01 & 3.66 & & & & & \\
\hline \multirow{3}{*}{$\begin{array}{l}\text { HUFAn-3: } \\
\text { LNA }\end{array}$} & Without & 2.19 & 0.62 & 3.15 & $1.84 \mathrm{~b}$ & & & & \\
\hline & With & 2.57 & 0.99 & 3.57 & $2.18 \mathrm{a}$ & $<0.0001$ & $<0.0001$ & 0.83 & 0.97 \\
\hline & Mean & $2.37 \mathrm{~B}$ & $0.81 \mathrm{C}$ & $2.85 \mathrm{~A}$ & & & & & \\
\hline \multirow{3}{*}{ HUFAn-6:LA } & Without & 0.26 & 0.26 & 0.34 & 0.28 & & & & \\
\hline & With & 0.28 & 0.26 & 0.31 & 0.28 & 0.0001 & 1.00 & 0.13 & 0.02 \\
\hline & Mean & $0.27 \mathrm{~B}$ & $0.26 \mathrm{~B}$ & $0.32 \mathrm{~A}$ & & & & & \\
\hline
\end{tabular}

SO - soybean oil; LO - linseed oil; FRO - fresh water fish residue oil; SEO - sesame oil; LA - linoleic acid; LNA - linolenic acid; SFA - saturated fatty acids; MUFA - monounsaturated fatty acids; PUFA - polyunsaturated fatty acids; HUFA - high-unsaturated fatty acids; DHA - docosahexaenoic acid; EPA - eicosapentaenoic acid; RSD - residual standard deviation. Within criterion, mean values with different lowercase and uppercase letters within columns and rows, respectively, are significantly different at $\mathrm{P}<0.05$.

\section{Discussion}

The lipid sources used in this trial proved suitable for addition to fish feed in different blends without affecting fish growth and production. Soy oil and linseed oil were chosen due to their different fatty acid compositions, namely predominance of LA and LNA, respectively. The partial substitution of fish oil with such plant oils in diets for marine and freshwater fish species has occurred in recent years (Nasopoulou and Zabetakis, 2012), due the high price of fish oil and the poor sustainability of conventional aquafeeds based on this ingredient.

Fish residue oil was included to evaluate the suitability of freshwater fish production and processing wastes as an ingredient for aquafeeds. The lipid profiles of oils extracted from animal wastes have a high oleic acid (C18:1n-9) content (Bureau and Meeker, 2010; Gonçalves et al., 2012).

The fatty acid profiles in the polar and neutral fractions were determined to verify the effects of dietary SEO additions, regarding the LA, LNA, and HUFA of the families n-3 and n- 6 percentages. According to Alhazzaa et al. (2018), fish as other vertebrates must be fed diets with preformed n-3 HUFA (EPA, DHA) and n-6 HUFA (AA) or the precursors (LA and LNA, respectively). However, the fatty acids quantities in diets depend on the capacity of each species to desaturate and elongate the LA and LNA, determined by the relative activity, availability, and affinity levels of their enzymes.

Besides having beneficial proprieties, $\mathrm{SEO}$ can also be used as a lipid source in fish diets. The combination of sunflower oil, linseed oil, fish residue oil, and SEO in diets of rainbow trout did not reduce weight gain or specific growth rate and did not increase the feed conversion rate (Köse and Yildiz, 2013). However, early juveniles of Lates calcarifer, a euryhaline catadromous species, responded to addition of sesamin to the diet with growth reduction (Alhazzaa et al., 2012).

Lambari, also known as yellowtail tetra, can adjust its gastrointestinal tract activity to utilize different ingredients (Sussel et al., 2014), such as the different oils used in this trial. Addition of oil extracted 
Table 6 - Main fatty acids, fatty acid groups, and relationships in the polar lipid fraction of lambari (values are expressed in g $100 \mathrm{~g}^{-1}$ of total fatty acids)

\begin{tabular}{|c|c|c|c|c|c|c|c|c|c|}
\hline \multirow{2}{*}{ Item } & \multirow{2}{*}{ SEO } & \multicolumn{3}{|c|}{ Oil Source (OS) } & \multirow{2}{*}{ Mean } & \multicolumn{3}{|c|}{ P-value } & \multirow{2}{*}{ RSD } \\
\hline & & SO & LO & FRO & & OS & SEO & $\mathrm{OS} \times \mathrm{SEO}$ & \\
\hline & Without & 1.31 & 1.30 & 1.32 & $1.31 \mathrm{a}$ & & & & \\
\hline \multirow[t]{3}{*}{ C12:0 } & With & 1.23 & 1.21 & 1.12 & $1.18 \mathrm{~b}$ & 0.74 & 0.03 & 0.62 & 0.12 \\
\hline & Mean & 1.27 & 1.25 & 1.22 & & & & & \\
\hline & Without & 1.63 & 1.66 & 1.70 & 1.66 & & & & \\
\hline \multirow[t]{3}{*}{ C14:0 } & With & 1.63 & 1.52 & 1.58 & 1.58 & 0.60 & 0.06 & 0.40 & 0.10 \\
\hline & Mean & 1.63 & 1.59 & 1.64 & & & & & \\
\hline & Without & 13.68 & 14.18 & 14.54 & $14.14 \mathrm{~b}$ & & & & \\
\hline \multirow[t]{3}{*}{ C16:0 } & With & 14.53 & 14.81 & 15.32 & $14.88 \mathrm{a}$ & 0.04 & 0.006 & 0.91 & 0.59 \\
\hline & Mean & 14.10B & $14.50 \mathrm{AB}$ & $14.93 \mathrm{~A}$ & & & & & \\
\hline & Without & 8.50 & 8.57 & 8.53 & 8.53 & & & & \\
\hline \multirow[t]{3}{*}{ C18:0 } & With & 8.58 & 8.74 & 8.80 & 8.70 & 0.68 & 0.19 & 0.84 & 0.31 \\
\hline & Mean & 8.54 & 8.65 & 8.66 & & & & & \\
\hline & Without & 17.01 & 17.81 & 17.49 & 17.44 & & & & \\
\hline \multirow[t]{3}{*}{ C18:1n-9 } & With & 18.59 & 18.65 & 19.54 & 18.93 & 0.61 & 0.02 & 0.70 & 1.42 \\
\hline & Mean & 17.80 & 18.23 & 18.52 & & & & & \\
\hline & Without & $7.71 \mathrm{a}$ & $6.23 a$ & $6.06 \mathrm{~b}$ & 6.66 & & & & \\
\hline \multirow[t]{3}{*}{ C18:2n-6 } & With & $7.31 \mathrm{a}$ & $7.06 \mathrm{a}$ & $7.12 \mathrm{a}$ & 7.16 & 0.008 & 0.046 & 0.044 & 0.57 \\
\hline & Mean & 7.51 & 6.64 & 6.59 & & & & & \\
\hline & Without & $0.88 a$ & $2.48 \mathrm{a}$ & $0.75 \mathrm{a}$ & 1.37 & & & & \\
\hline \multirow[t]{3}{*}{ C18:3n-3 } & With & $0.75 \mathrm{~b}$ & $1.54 \mathrm{~b}$ & $0.71 \mathrm{a}$ & 1.01 & $<0.0001$ & $<0.0001$ & $<0.0001$ & 0.12 \\
\hline & Mean & 0.84 & 2.01 & 0.73 & & & & & \\
\hline & Without & $7.26 \mathrm{a}$ & $4.11 \mathrm{~b}$ & $7.70 \mathrm{a}$ & 6.36 & & & & \\
\hline \multirow[t]{3}{*}{ C20:4n-6 } & With & $7.40 \mathrm{a}$ & $5.77 a$ & $7.69 a$ & 6.96 & $<0.0001$ & 0.005 & 0.003 & 0.46 \\
\hline & Mean & 7.33 & 4.94 & 7.70 & & & & & \\
\hline & Without & $1.49 \mathrm{a}$ & $2.87 \mathrm{a}$ & $1.23 \mathrm{a}$ & 1.87 & & & & \\
\hline \multirow[t]{3}{*}{ C20:5n-3 } & With & $1.26 \mathrm{a}$ & $2.25 \mathrm{~b}$ & $1.20 \mathrm{a}$ & 1.57 & $<0.0001$ & $<0.0001$ & 0.0005 & 0.12 \\
\hline & Mean & 1.38 & 2.56 & 1.22 & & & & & \\
\hline & Without & 14.69 & 17.19 & 13.73 & $15.20 \mathrm{a}$ & & & & \\
\hline \multirow[t]{3}{*}{ C22:6n-3 } & With & 13.29 & 15.76 & 12.20 & $13.73 \mathrm{~b}$ & $<0.0001$ & 0.002 & 0.99 & 0.75 \\
\hline & Mean & 13.99B & $16.48 \mathrm{~A}$ & $12.96 \mathrm{~B}$ & & & & & \\
\hline & Without & 28.86 & 29.55 & 30.04 & 29.48 & & & & \\
\hline \multirow[t]{3}{*}{$\Sigma$ SFA } & With & 29.68 & 29.67 & 29.97 & 29.77 & 0.046 & 0.21 & 0.25 & 0.54 \\
\hline & Mean & $29.27 \mathrm{~B}$ & $29.61 \mathrm{AB}$ & $30.00 \mathrm{~A}$ & & & & & \\
\hline & Without & 23.87 & 24.63 & 24.75 & 24.41 & & & & \\
\hline \multirow[t]{3}{*}{$\Sigma$ MUFA } & With & 25.55 & 24.72 & 26.32 & 25.53 & 0.38 & 0.06 & 0.44 & 1.37 \\
\hline & Mean & 24.71 & 24.67 & 25.54 & & & & & \\
\hline & Without & 47.27 & 45.82 & 45.20 & $46.09 a$ & & & & \\
\hline \multirow[t]{3}{*}{$\Sigma$ PUFA } & With & 44.77 & 45.61 & 43.71 & $44.69 \mathrm{~b}$ & 0.15 & 0.049 & 0.38 & 1.62 \\
\hline & Mean & 46.02 & 45.71 & 44.45 & & & & & \\
\hline & Without & $23.50 \mathrm{a}$ & $15.88 \mathrm{~b}$ & $22.78 \mathrm{a}$ & 20.71 & & & & \\
\hline \multirow[t]{3}{*}{ ¿PUFAn-6 } & With & $23.22 \mathrm{a}$ & $19.57 a$ & $23.75 a$ & 22.18 & $<0.0001$ & $<0.0001$ & $<0.0001$ & 0.71 \\
\hline & Mean & 23.36 & 17.73 & 23.24 & & & & & \\
\hline & & & & & & & & \multicolumn{2}{|c|}{ Continues... } \\
\hline
\end{tabular}




\begin{tabular}{|c|c|c|c|c|c|c|c|c|c|}
\hline \multirow{3}{*}{ ¿PUFAn-3 } & Without & 19.50 & 25.73 & 18.04 & $21.10 \mathrm{a}$ & & & & \\
\hline & With & 17.50 & 22.15 & 16.13 & $18.59 \mathrm{~b}$ & $<0.0001$ & $<0.0001$ & 0.29 & 1.14 \\
\hline & Mean & $18.50 \mathrm{~B}$ & $23.94 \mathrm{~A}$ & $17.08 \mathrm{C}$ & & & & & \\
\hline \multirow{3}{*}{$\begin{array}{l}\text { PUFAn-6: } \\
\text { PUFAn-3 }\end{array}$} & Without & 1.21 & 0.62 & 1.26 & $1.02 \mathrm{~b}$ & & & & \\
\hline & With & 1.33 & 0.88 & 1.48 & $1.24 \mathrm{a}$ & $<0.0001$ & $<0.0001$ & 0.22 & 0.08 \\
\hline & Mean & $1.26 \mathrm{~B}$ & $0.75 \mathrm{C}$ & $1.37 \mathrm{~A}$ & & & & & \\
\hline \multirow{3}{*}{ PUFA:SFA } & Without & 1.64 & 1.55 & 1.50 & 1.54 & & & & \\
\hline & With & 1.50 & 1.53 & 1.46 & 1.50 & 0.08 & 0.05 & 0.28 & 0.07 \\
\hline & Mean & 1.57 & 1.54 & 1.48 & & & & & \\
\hline \multirow{3}{*}{ DHA:EPA } & Without & $9.84 a$ & $5.99 \mathrm{~b}$ & $11.17 \mathrm{a}$ & 8.99 & & & & \\
\hline & With & $10.64 a$ & $7.01 \mathrm{a}$ & $10.19 a$ & 9.28 & $<0.0001$ & 0.30 & 0.01 & 0.66 \\
\hline & Mean & 10.24 & 6.50 & 10.68 & & & & & \\
\hline \multirow{3}{*}{$\begin{array}{l}\text { HUFAn-3: } \\
\text { LNA }\end{array}$} & Without & $21.17 \mathrm{a}$ & $9.48 \mathrm{a}$ & $23.00 \mathrm{a}$ & 17.87 & & & & \\
\hline & With & $21.23 a$ & $13.49 \mathrm{~b}$ & $21.59 a$ & 18.77 & $<0.0001$ & 0.29 & 0.04 & 2.01 \\
\hline & Mean & 21.20 & 11.49 & 22.30 & & & & & \\
\hline \multirow{3}{*}{ HUFAn-6:LA } & Without & 2.06 & 1.55 & 2.79 & 2.13 & & & & \\
\hline & With & 2.20 & 1.78 & 2.34 & 2.11 & $<0.0001$ & 0.81 & 0.06 & 0.29 \\
\hline & Mean & $2.13 \mathrm{~B}$ & $1.67 \mathrm{C}$ & $2.56 \mathrm{~A}$ & & & & & \\
\hline
\end{tabular}

SO - soybean oil; LO - linseed oil; FRO - fresh water fish residue oil; SEO - sesame oil; LA - linoleic acid; LNA - linolenic acid; SFA - saturated fatty acids; MUFA - monounsaturated fatty acids; PUFA - polyunsaturated fatty acids; HUFA - high-unsaturated fatty acids; DHA - docosahexaenoic acid; EPA - eicosapentaenoic acid; RSD - residual standard deviation.

Within criterion, mean values with different lowercase and uppercase letters within columns and rows, respectively, are significantly different at $\mathrm{P}<0.05$.

from salmon and tilapia residues to feed did not affect the growth and development of lambari (Gonçalves et al., 2012). This species can also assimilate synthetic compounds such as conjugated linoleic acid without growth reduction or decreased specific growth rate and with increased feed conversion (Campelo et al., 2015).

The different types of oil in lambari feed proved to be suitable alternative lipid sources that modulate fish physiology and the chemical composition of their flesh. In a previous study (Natori et al., 2016), lambari fed a diet including LO showed higher TBARS formation than those fed diets containing LO combined with SEO. The ability of SEO to reduce oxidation processes was also demonstrated in diabetic rats. When fed diets containing SEO, free radical formation decreased; moreover, the sesamolin contained in SEO reduced hepatic TBARS values in normal rats (Kang et al., 1998; Ramesh et al., 2005).

In the marine species Atlantic salmon (Salmo salar L.) and Atlantic cod (Gadus morhua), the inclusion of highly unsaturated and oxidized oil in feed increased hepatic TBARS due to intestinal absorption of malondialdehyde or due to hydroperoxides formed by peroxidation of fatty acids present in tissues (Hamre et al., 2001; Kjær et al., 2008). In our trial, lambari fed FRO diets showed higher GR activities than those fed SO and LO diets, suggesting that the oxidation level of FRO affected the values of this variable.

Reduced GR activity in muscle of animals fed SEO diet can be due to the probable presence of bioactive compounds such as sesamin/episamin and tocopherols (Fukuda et al., 1986; Chung et al., 2004). Sesamin is metabolized in the liver and becomes effective at reducing free radicals such as superoxides. However, at high concentrations, this compound may cause oxidative damage (Jeng and Hou, 2005).

The lower enzyme activity of lactate dehydrogenase (LDH) after addition of SEO to the diet could also be related to the presence of sesamin lignan. In neurons, sesamin inhibits free radical formation and downregulates the release and activity of $\mathrm{LDH}$, activated by hypoxia, preserving CAT and superoxide dismutase activities (Jeng and Hou, 2005). The lignan compound in SEO can modulate the formation 
and quantities of DHA, as demonstrated by studies with rainbow trout muscle, Atlantic salmon hepatocytes, and Lates calcarifer fillets (Trattner et al., 2008a,b; Alhazzaa et al., 2012). In an in vitro study, the expression of CTP1, involved in $\beta$-oxidation, was higher in hepatocytes of Atlantic salmon fed sesamin in the diet (Trattner et al., 2008b).

The neutral fraction of lipids consists mainly of triglycerides stocked in adipose tissue, and their composition is influenced by species, season, and diet. The polar fraction, consisting mainly of phospholipids and glycolipids, composes the membrane structures and is highly susceptible to the lipid peroxidation due to its high PUFA content (Bao and Ohshima, 2014).

Differences in neutral fatty acid composition between treatments may influence fish growth maintenance and other physiological events such as reproduction or even the immune system (Turchini et al., 2010). Phospholipids are important components of the lipid profile, since they establish membrane fluidity and have a role in controlling cell functions (Clandinin et al., 1991). Differences in LA, LNA, AA, EPA, and DHA percentages caused by different oils in fish diets may alter some fish functions such as eicosanoid synthesis, the epidermal barrier, and free radical formation (Spector, 1999).

Similar effects of SEO and its combinations were also observed in the polar and neutral fractions. In rainbow trout, the combination of SEO, LO, and sunflower oil in fish feed promoted formation of C20:3n-3, demonstrating desaturation and elongation capacity through activation of $\Delta 5$ and $\Delta 6$ desaturase (Köse and Yildiz, 2013). In the present study, the addition of SEO to feed may have interfered with the quantities of EPA and DHA, due to the probable higher desaturation rate of LNA to HUFAn-3 and the higher DHA:EPA ratio in fish fed the LO+SEO diet than in fish fed the LO diet. Oxidation of fatty acids produces hydroperoxides by activation of PPAR $\alpha$ and other secondary compounds (Takahashi et al., 2002). In our study, fish fed the LO diet showed a higher proportion of PUFA and a low PUFAn-6:PUFAn-3 ratio. This result may be related to the capacity of LO to produce LNA and, consequently, to promote an increase in EPA and DHA levels (Tocher, 2003).

The PUFAn-6:PUFAn-3 ratio is higher in freshwater than in salt water species, due to the higher proportion of PUFAn-6, mainly in the form of linoleic acid. According to Valfré et al. (2003), the PUFAn-6:PUFAn-3 ratio normally varies between 1 and 4. The higher MUFA and lower PUFA contents found in lambari fed the FRO and FRO+SEO diets are related to the higher level of oleic acid in waste generated by freshwater fish production and processing, from which FRO was obtained.

The effects of the alternative oil sources tested in this trial on the fatty acid profile of lambari depend on the physiological characteristics of this tropical fish species. As other tropical freshwater species, lambari probably can desaturate and elongate LA into AA and LNA into EPA and DHA, thus modifying dietary fatty acids by a metabolic process (Gonçalves et al., 2012).

\section{Conclusions}

The addition of sesame oil to the alternative lipid sources tested in this trial (i.e., soybean oil, linseed oil, and freshwater fish residue oil) may improve the fatty acid profile of lambari and may increase the desaturation rate of linolenic acid into HUFAn-3 levels of the polar and neutral fractions. The addition also protects these fatty acids from oxidation by alleviating the negative effects of oxygen free radicals in muscle, without impairing fish performance. Linseed oil promotes better fatty acid profile but may induce higher susceptibility to free radicals.

Furthermore, sesame oil added to the lambari diet improves fish quality by the probable increased production of highly unsaturated fatty acids and by reducing the activity of oxidative enzymes such as glutathione reductase and lactate dehydrogenase, without damaging the growth of fish.

\section{Acknowledgments}

The authors thank the Fundação de Amparo à Pesquisa do Estado de São Paulo (FAPESP), for the financial support (2012/11101-0); Conselho Nacional de Desenvolvimento Científico e Tecnológico 
(CNPq), for the doctoral scholarship (141857/2012-9); and Ciências sem Fronteiras for the scholarship at the Florence University of the first author (202584/2014-3). Thanks are also due to the University of Florence that contributed to this research with the Ateneo Funding (ex-60\%); to Nosso Recanto trout farm (Sapucaí Mirim, MG, Brazil), for giving the freshwater fish residue oil; and to Unidade de Pesquisa e Desenvolvimento de Pirassununga, Instituto de Pesca (Pirassununga, São Paulo), for donating the animals used in the experiment.

\section{References}

AOAC - Association of Official Analytical Chemists. 1990. Official methods of the analysis of AOAC International. 15th ed. AOAC International, Arlington, VA, USA.

AOAC - Association of Official Analytical Chemists. 2005. Official methods of analysis of AOAC International. 18th ed. AOAC International, Gaithersburg, MA, USA.

Abimorad, E. G. and Castellani, D. 2011. Exigências nutricionais de aminoácidos para o lambari-do-rabo amarelo baseadas na composição da carcaça e do músculo. Boletim do Instituto de Pesca 37:31-38.

Alhazzaa, R.; Bridle, A. R.; Carter, C. G. and Nichols, P. D. 2012. Sesamin modulation of lipid class and fatty acid profile in early juvenile teleost, Lates calcarifer, fed different dietary oils. Food Chemistry 134:2057-2065. https://doi.org/10.1016/j. foodchem.2012.04.004

Alhazzaa, R.; Nichols, P. D. and Carter, C. G. 2018. Sustainable alternatives to dietary fish oil in tropical fish aquaculture. Reviews in Aquaculture, https://doi.org/10.1111/raq.12287 (in press).

Bao, H. N. D. and Ohshima, T. 2014. Strategies to minimize lipid oxidation of aquatic food products post harvest. p.95-125. InKristinsson, H. G., ed. Antioxidants and functional components in aquatic foods. John Wiley \& Sons Ltd, New Jersey, USA.

Beers, R. F. and Sizer, I. W. 1952. A spectrophotometric method for measuring the breakdown of hydrogen peroxide by catalase. The Journal of Biological Chemistry 195:133-140.

Bernt, E. and Bergmeyer, H. U. 1974. Lactate dehydrogenase assay. Methods of enzymatic analysis. Academic Press, London.

Bradford, M. M. 1976. A rapid and sensitive method for the quantification of microgram quantities of protein utilizing the principle of protein-dye binding. Analytical Biochemistry 72:248-254. https://doi.org/10.1016/0003-2697(76)90527-3

Bureau, D. and Meeker, D. L. 2010. Terrestrial animal fats. p.245-266. In: Fish oil replacement and alternative lipid sources in aquaculture feeds. Turchini. G. M.; Ng, W.-K. and Tocher, D. R., eds. CRC Press, Taylor and Francis Group, Boca Raton, FL, USA.

Campelo, D. A. V.; De Oliveira, K. R. B.; Batiston, W. P.; Zuanon, J. A. S.; Furuya, W. M.; Matsushita, M. and Salaro, A. L. 2015. Conjugated linoleic acid in diets for lambari (Astyanax altiparanae) (Garutti \& Britski, 2000). Aquaculture Nutrition 21:788-796. https://doi.org/10.1111/anu.12203

Carlberg, I. and Mannervik, B. 1985. Glutathione reductase. Methods in Enzymology 113:484-490.

Chung, J.; Lee, J. and Choe, E. 2004. Oxidative stability of soybean and sesame oil mixture during frying of flour dough. Journal of Food Science 69:574-578. https://doi.org/10.1111/j.1365-2621.2004.tb13652.x

Clandinin, M.; Cheema, S.; Field, C. J.; Garg, M. L.; Venkatraman, J. and Clandinin, T. R. 1991. Dietary fat: exogenous determination of membrane structure and cell function. FASEB Journal 5:2761-2769.

Folch, J.; Lees, M. and Sloane Stanley, G. H. 1957. A simple method for the isolation and purification of total lipids from animal tissues. Journal of Biological Chemistry 226:497-509.

Fukuda, Y.; Nagata, M.; Osawa, T. and Namiki, M. 1986. Contribution of lignan analogues to antioxidative activity of refined unroasted sesame seed oil. Journal of the American Oil Chemists' Society 63:1027-1031. https://doi.org/10.1007/ BF02673792

Gonçalves, L. U.; Ferroli, F. and Viegas, E. M. M. 2012. Effect of the inclusion of fish residue oils in diets on the fatty acid profile of muscles of males and females lambari (Astyanax altiparanae). Revista Brasileira de Zootecnia 41:1967-1974. https://doi.org/10.1590/S1516-35982012000900001

Gonçalves, L. U.; Parisi, G.; Bonelli, A.; Sussel, F. R. and Viegas, E. M. M. 2014. The fatty acid compositions of total, neutral and polar lipids in wild and farmed lambari (Astyanax altiparanae) (Garutti \& Britski, 2000) broodstock. Aquaculture Research 45:195-203. https://doi.org/10.1111/j.1365-2109.2012.03215.x

Hamre, K.; Kolås, K.; Sandnes, K.; Julshamn, K. and Kiessling, A. 2001. Feed intake and absorption of lipid oxidation products in Atlantic salmon (Salmo salar) fed diets coated with oxidised fish oil. Fish Physiology and Biochemistry 25:209-219. https://doi.org/10.1023/A\%3A1022257928437

Jeng, K. C. G. and Hou, R. C. W. 2005. Sesamin and sesamolin: nature's therapeutic lignans. Enzyme 1:11-20.

R. Bras. Zootec., 48:e20170240, 2019 
Juaneda, P. and Rocquelin, G. 1985. Rapid and convenient separation of phospholipids and non phosphorus lipids from rat heart using silica cartridges. Lipids 20:40-41. https://doi.org/10.1007/BF02534360

Kang, M. H.; Naito, M.; Tsujihara, N. and Osawa, T. 1998. Sesamolin inhibits lipid peroxidation in rat liver and kidney. The Journal of Nutrition 128:1018-1022. https://doi.org/10.1093/jn/128.6.1018

Kjær, M. A.; Todorčević, M.; Torstensen, B. E.; Vegusdal, A. and Ruyter, B. 2008. Dietary n-3 HUFA affects mitochondrial fatty acid $\beta$-oxidation capacity and susceptibility to oxidative stress in Atlantic salmon. Lipids 43:813-827. https://doi. org/10.1007/s11745-008-3208-z

Köse, I. and Yildiz, M. 2013. Effect of diets containing sesame oil on growth and fatty acid composition of rainbow trout (Oncorhynchus mykiss). Journal of Applied Ichthyology 29:1318-1324. https://doi.org/10.1111/jai.12184

Morrison, W. R. and Smith, L. M. 1964. Preparation of fatty acid methyl esters and dimethylacetals from lipids with boron fluoride-methanol. Journal of Lipid Research 5:600-608.

Natori, M. M.; Alves, R. C. P.; Oliveira, R. H. F.; Segura, J. G. and Viegas, E. M. M. 2016. Sesame oil in diets for lambari: effects on growth parameters, corporal chemical composition and physiological alterations. Ciência Rural 46:1274-1280. https://doi.org/10.1590/0103-8478cr20151011

Nasopoulou, C. and Zabetakis, I. 2012. Benefits of fish oil replacement by plant originated oils in compounded fish feeds. Food Science and Technology 47:217-224. https://doi.org/10.1016/j.lwt.2012.01.018

Ng, W. K.; Chong, C. Y.; Wang, Y. and Romano, N. 2013. Effects of dietary fish and vegetable oils on the growth, tissue fatty acid composition, oxidative stability and vitamin E content of red hybrid tilapia and efficacy of using fish oil finishing diets. Aquaculture 372-375:97-110. https://doi.org/10.1016/j.aquaculture.2012.10.030

Pereira-da-Silva, E. M.; Oliveira, R. H. F.; Ribeiro, M. A. R. and Coppola, M. P. 2009. Efeito anestésico do óleo de cravo em alevinos de lambari. Ciência Rural 39:1851-1856. https://doi.org/10.1590/S0103-84782009005000127

Ramesh, B.; Saravanan, R. and Pugalendi, K. V. 2005. Influence of sesame oil on blood glucose, lipid peroxidation, and antioxidant status in streptozotocin diabetic rats. Journal of Medicinal Food 8:377-381. https://doi.org/10.1089/ jmf.2005.8.377

Spector, A. A. 1999. Essentiality of fatty acids. Lipids 34:S1-S3.

Sussel, F. R.; Viegas, E. M. M.; Evangelista, M. M.; Gonçalves, G. S.; Salles, F. A. and Gonçalves, L. U. 2014. Replacement of animal protein with vegetable protein in the diets of Astyanax altiparanae. Acta Scientiarum. Animal Sciences 36:343-348.

Takahashi, M.; Tsuboyama-Kasaoka, N.; Nakatani, T.; Ishii, M.; Tsutsumi, S.; Aburatani, H. and Ezaki, O. 2002. Fish oil feeding alters liver gene expressions to defend against PPAR $\alpha$ activation and ROS production. American Journal of Physiology Gastrointestinal and Liver Physiology 282:338-348. https://doi.org/10.1152/ajpgi.00376.2001

Tocher, D. R. 2003. Metabolism and functions of lipids and fatty acids in teleost fish. Reviews in Fisheries Science 11:107-184. https://doi.org/10.1080/713610925

Trattner, S.; Kamal-Eldin, A.; Brännäs, E.; Moazzami, A.; Zlabek, V.; Larsson, P.; Ruyter, B.; Gjøen, T. and Pickova, J. 2008a. Sesamin supplementation increases white muscle docosahexaenoic acid (DHA) levels in rainbow trout (Oncorhynchus mykiss) fed high alpha-linolenic acid (ALA) containing vegetable oil: Metabolic actions. Lipids 43:989-997. https://doi.org/10.1007/s11745-008-3228-8

Trattner, S.; Ruyter, B.; Østbye, T. K.; Gjøen, T.; Zlabek, V.; Kamal-Eldin, A. and Pickova, J. 2008b. Sesamin increases alpha-linolenic acid conversion to docosahexaenoic acid in Atlantic salmon (Salmo salar L.) hepatocytes: Role of altered gene expression. Lipids 43:999-1008. https://doi.org/10.1007/s11745-008-3229-7

Turchini, G. M.; Ng, W. and Tocher, D. R. 2010. Fish oil replacement and alternative lipid sources in aquaculture feeds. CRC Press, Inc., Boca Raton, Florida, USA.

Turchini, G. M.; Torstensen, B. E. and Ng, W. K. 2009. Fish oil replacement in finfish nutrition. Reviews in Aquaculture 1:10-57. https://doi.org/10.1111/j.1753-5131.2008.01001.x

Valfré, F.; Caprino, F. and Turchini, G. M. 2003. The health benefit of seafood. Veterinary Research Communications 27:507-512. https://doi.org/10.1023/B:VERC.0000014208.47984.8c 